Robert M. Friesen MD FRCP(C), Jorge F. Bonet MD FRCP(C)

\title{
The antiarrhythmic effects of verapamil and propranolol in aminophylline toxic dogs
}

The antiarrhythmic effects of the calcium blocker verapamil and the beta adrenoreceptor blocker propranolol were examined in aminophylline toxic dogs. Eighteen dogs were intubated and ventilated after induction of anaesthesia (pentobarbitone $30 \mathrm{mg} / \mathrm{kg}$ and paccuronium $0.1 \mathrm{mg} / \mathrm{kg}$ ). All animals were rendered toxic by aminophylline infusion; an initial dose of $50 \mathrm{mg} / \mathrm{kg}$ over five minutes with subsequent doses of $10 \mathrm{mg} / \mathrm{kg}$ over 30 seconds. Twenty minutes after each aminophylline infusion, the dog was challenged with phenylephrine (10 to $20 \mu \mathrm{g} / \mathrm{kg}$ ). This resulted in short duration hypertension and reproducible emergence of ventricular arrhythmias. The dogs were divided into three groups of six animals each. Group I (control) received no antiarrhythmics whereas Group II received verapamil $0.2 \mathrm{mg} / \mathrm{kg}$ and Group III received propranolol $0.1 \mathrm{mg} / \mathrm{kg}$ for the treatment of persistent ventricular arrhythmias. Both verapamil and propranolol exerted an antiarrhythmic effect in aminophylline induced ventricular arrhythmias. The efficacy of verapamil was independent of the accompanying reduction in blood pressure and systemic vascular resistance as subsequent phenylephrine induced hypertensian could not reinstitute these arrhythmias. Propranolol appeured less effective since it did not completely suppress the arrhythmias in shree dogs and could not prevent emergence of $P V C$ 's in four following repeat phenylephrine challenge. Further development of

From the Department of Anaesthesia, Health Sciences Centre and the Department of Pharmacology \& Therapeutics, Faculty of Medicine, University of Manitoba.

Address correspondence to: Dr. Robert M. Friesen, Department of Anaesthesia, St. Boniface General Hospital, 409 Taché Avenue, Winnipeg, Manitoba R2H 2 A6 this animal model may be useful for the better understanding of ventricular arrhythmias.

\section{Key words}

TOXICITY: ventricular arrhythmias, aminophylline; HEART: antiarrhythmics; ANTIARRHYTHMICS: verapamil, propranolol.

Potentially lethal cardiac arrhythmias are a cardiovascular complication of severe aminophylline toxicity. ${ }^{1}$ Despite the serious inplications of these rhythm disturbances, little clinical and experimental information concerning the rational pharmacologic approach to this problem is available. Furthermore, much of the knowledge encompassing the medical management of arrhythmias was obtained from numerous experimental and clinical models which might not reproduce the electrical behaviour of the aminophylline toxic heart and thus are not totally applicable to this problem. ${ }^{2}$ Moreover, the multiple cardiovascular and systemic effects of aminophylline secondary to phosphodiesterase inhibition, stimulation of catecholamine synthesis and release as well as altered intra-cellular calcium kinetic $s^{3}$ can severely limit the usefulness of many antiarrhythmic agents.

In an effort to better understand these arrhythmias and to provide a more rational approach to their pharmacologic management, we independently investigated the calcium channel blocker verapamil and the beta adrenoreceptor blocker propranolol in aminophylline toxic dogs.

\section{Methods}

Eighteen dogs were intubated and ventilated after induction of anaesthesia (pentobarbitone $30 \mathrm{mg} / \mathrm{kg}$ 


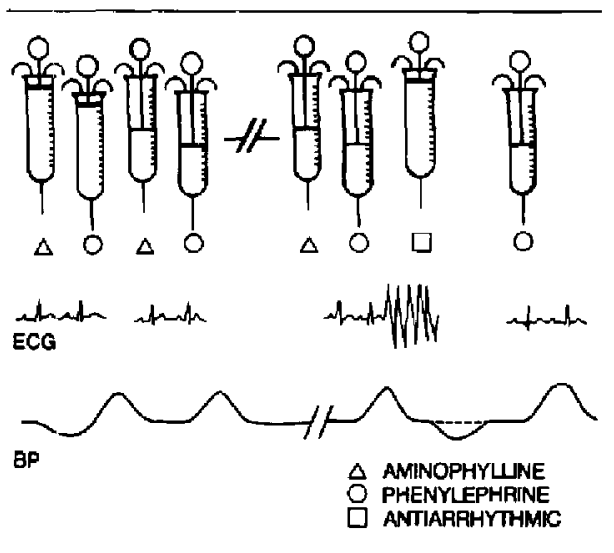

FIGURE 1 Summary of experimental model: As described in the method and summarized in Table I, repetitive aminophylline infusions $(\Delta)$ followed by phenylephrine $(O)$ induced hypestension were continued until persistent ventricular arthythmias resulted. Antiarthythmic therapy ( $\square$ ) was thes given, followed by a further phenylephrine challenge to establish whether the arrhythmias would recur. Graphic representation of electrocardiogram (ECG) and mean arterial blood pressure (BP) are also shown.

and pancuronium $0.1 \mathrm{mg} / \mathrm{kg}$ ). Supplemental pentobarbitone ( $2 \mathrm{mg} / \mathrm{kg}$ ) was given qlh and as required. Electrocardiogram, arterial blood pressure and left ventricular end diastolic pressure were continuously monitored and recorded. Cardiac output and systemic vascular resistance were computed by thermodilution technique using a Swan Ganz catheter. A separate right atrial catheter was placed for cold saline injection. Serum electrolytes including calcium, arterial blood gas tensions $\mathrm{pH}$ and serial aminophylline levels were measured.

All animals were rendered toxic by aminophylline infusion, an initial dose of $50 \mathrm{mg} / \mathrm{kg}$ over five minutes with subsequent doses of $10 \mathrm{mg} / \mathrm{kg}$ over 30 seconds. Twenty minutes after each aminophylline infusion the dog was challenged with phenylephrine $(10-20 \mu \mathrm{g} / \mathrm{kg})$. This resulted in short duration hypertension, and reproducible emergence of ventricular arrhythmias when a toxic aminophylline level was reached. The dogs continued to receive additional aminophylline infusions followed by substquent phenylephrine challenge until these arrhythmias persisted over a 120-second observation period (Fig. 1). Arrhythmias were defincd as frequent ventricular ectopics, ventricular tachycar-
TABLE I Events summary

1. Control

2. Phenylephrine challenge

3. Return to control

4. Ten minutes post initial aminophylline infusion ( $50 \mathrm{mg} / \mathrm{kg}$ over $5 \mathrm{mins}$ )

5. Post additional aminophylline infusion and before persistent arthythmia

6. Arrhythmia onset

7. Persistent arrhythmi

8. Post therapeutic intervention

Note: Odd numbered events represent data collection points prior to further intervention.

dia or ventricular fibrillation. The dogs were divided into three groups of six animals each. Group I (control) received no antiarrhythmics whereas Group II received verapamil $0.2 \mathrm{mg} / \mathrm{kg}$ over 30 seconds and Group III received propranolol $0.1 \mathrm{mg} / \mathrm{kg}$ over 30 seconds for the treatment of persistent ventricular arrhythmias. After antiarrhythmic therapy the dogs were rechallenged with phenylephrine.

Ventricular ectopics were defined by the presence of at least three of the following criteria: (1) the QRS complex was different than a sinus conducted impulse; (2) no evidence of rate-related aberrant conduction; (3) QRS duration was greater than $120 \mathrm{msec}$; (4) presence of occasional fusion beats; (5) presence of a full compensatory pause. Criteria for ventricular tachycardia included: (1) QRS duration of greater than 120 msec; (2) QRS complex different from a sinus conducted pulse; (3) no evidence of rate-related aberrancy with atrial rates faster than the defined arrhythmias; (4) presence of fusion and capture beats; (5) presence of complete atrioventricular dissociation.

Although data were continuously recorded, pre, during and post specific event points were chosen for analysis (Table I). Analysis of data was by paired t-test, $p<0.05$ was considered significant. All values are recorded as mean \pm standard deviation.

All arrhythmias were confirmed by a cardiologist who was not informed of the experimental group at the time of evaluation.

\section{Results}

All dogs in Group I dicd of ventricular arrhythmias when the serum aminophylline level reached $153 \pm$ 
ECGII

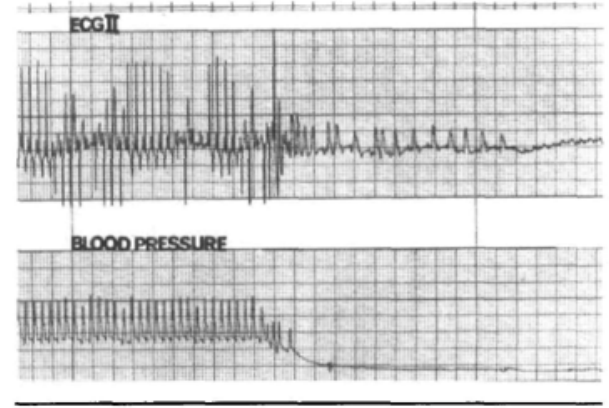

FIGURE 2 Example of terminal ventricular arhythmia in control group (paper speed - $5 \mathrm{~mm} / \mathrm{sec}$ ).

TABLE II Serum aminophylline levels*

\begin{tabular}{ll}
\hline Group I & $152.0 \pm 23.3 \mu \mathrm{g} / \mathrm{ml}$ \\
Group II & $131.2 \pm 47.0 \mu \mathrm{g} / \mathrm{ml}$ \\
Group III & $145.5 \pm 24.9 \mu \mathrm{g} / \mathrm{ml}$ \\
\hline
\end{tabular}

*Recorded at the time of sustained ventricular arthythmia. Mean \pm S.D.

No significant difference between all 3 groups.

$23.3 \mu \mathrm{g} / \mathrm{ml}$ (Fig. 2). There was no significant difference between the serum aminophylline levels at the time of persistent ventricular arrhythmia in all three groups (Table II). Analysis of biochemical, blood gas tensions and $\mathrm{pH}$ data showed no significant difference between the three groups (Table III).

The haemodynamic, chronotropic and electrophysiologic effects of aminophylline are summarized in Table IV (columns A and C). These results are similar to those reported by others. ${ }^{4}$
In Group II these arrhythmias were promptly terminated by verapamil in all six dogs (mean time $99 \pm 47.8$ seconds). As summarized in Table IV (column B) and Figure 3, verapamil resulted in a 33.3 per cent decrease in arterial blood pressure while systemic vascular resistance fell 41.4 per cent. Transient second degree atrioventricular block (mean time 52 seconds) and subsequent PR interval prolongation were also noted. Repeat phenylephrine challenge did not re-institute these arrhythmias in any dog in this group (Table V).

In Group III propranolol resulted in rapid (mean time $83 \pm 77$ seconds) but partial arrhythmia control, three dogs requiring additional doses of propranolol. Significant changes observed with the administration of propranolol included heart rate slowing, prolongation of the PR interval and a decrease in cardiac index (Table IV (column D) and Figure 4). Subsequent phenylephrine challenge resulted in transient ventricular ectopics in 4 dogs (Table V).

\section{Discussion}

This study demonstrated that verapamil and propranolol in therapeutic doses were effective antiarrhythmics in aminophylline toxic dogs. Our observations differ slightly from previously published information, ${ }^{3,5}$ in that our animals required consistently higher serum aminophylline levels to develop arrhythmias. Despite this, the serum levels of aminophylline seen in our study are not different from those reported from clinical experience.' Furthermore, these high levels of aminophylline did

TABLE III Biochemical and blood gas results

\begin{tabular}{lccc}
\hline & $\begin{array}{l}\text { Group I } \\
\text { (control) }\end{array}$ & $\begin{array}{l}\text { Group II } \\
\text { (verapamil) }\end{array}$ & $\begin{array}{l}\text { GrouplII } \\
\text { (propranolol) }\end{array}$ \\
\hline Sodium (mmol/l) & $144.7 \pm 2.7$ & $144.3 \pm 2.3$ & $145.5 \pm 1.9$ \\
Potassium (mmol/l) & $3.6 \pm 0.4$ & $3.5 \pm 0.1$ & $3.6 \pm 0.4$ \\
Chloride (mmol/) & $114.2 \pm 4.0$ & $114.2 \pm 3.9$ & $114.7 \pm 3.1$ \\
Bun (mmol/l) & $2.69 \pm 0.48$ & $2.52 \pm 0.40$ & $2.04 \pm 0.17$ \\
Creatinine (mmol/l) & $0.071 \pm 0.018$ & $0.071 \pm 0.009$ & $0.062 \pm 0.009$ \\
Glucose (mmol/l) & $6.05 \pm 1.50$ & $6.92 \pm 0.97$ & $6.29 \pm 0.34$ \\
Total calcium (mmol/) & $2.46 \pm 0.12$ & $2.48 \pm 0.09$ & $2.50 \pm 0.15$ \\
lonized calcium (mmol/l) & $1.30 \pm 0.08$ & $1.33 \pm 0.05$ & $1.36 \pm 0.08$ \\
PaO 2 (Kpa) & $13.13 \pm 1.49$ & $13.00 \pm 1.41$ & $13.51 \pm 0.67$ \\
PaCO $(\mathrm{Kpa})$ & $4.30 \pm 0.84$ & $4.62 \pm 0.61$ & $4.23 \pm 0.51$ \\
$\mathrm{pH}$ & $7.43 \pm 0.08$ & $7.39 \pm 0.04$ & $7.43 \pm 0.04$ \\
Bicarbonate (mmol/l) & $20.8 \pm 2.0$ & $20.8 \pm 2.2$ & $20.6 \pm 1.5$ \\
\hline
\end{tabular}

All values mean \pm S.D. 
TABLE IV Haenodynamic results (\% changes)

\begin{tabular}{|c|c|c|c|c|}
\hline \multirow[b]{2}{*}{ Event } & \multicolumn{2}{|l|}{ Group II (verapamil) } & \multicolumn{2}{|c|}{ Grosp III (propranolol) } \\
\hline & $\begin{array}{l}\text { Post aminophylline } \\
50 \mathrm{mg} / \mathrm{kg}\end{array}$ & $\begin{array}{l}\text { Post arrhythmia } \\
\text { intervention }\end{array}$ & $\begin{array}{l}\text { Post aminophylline } \\
50 \mathrm{mg} / \mathrm{kg}\end{array}$ & $\begin{array}{l}\text { Post arrhyshmia } \\
\text { intervention }\end{array}$ \\
\hline Column & $A$ & $\mathbf{B}$ & $\mathrm{C}$ & $\mathrm{D}$ \\
\hline \multicolumn{5}{|l|}{ Mean arterial } \\
\hline pressure & $-35.7 \%$ & $-33.3 \% \dagger$ & $-35.1 \% *$ & $-0.2 \%$ \\
\hline PR Interval & $-15.0 \% \neq$ & $+78.8 \% \ddagger$ & $-15.2 \% \dagger$ & $+75.0 \%^{*}$ \\
\hline Heart rate & $+34.4 \% \ddagger$ & $-7.3 \%$ & $+38.7 \% *$ & $-15.7 \% \ddagger$ \\
\hline $\begin{array}{l}\text { Cardialc index } \\
\text { Systernic vascular }\end{array}$ & $+52.9 \%$ & $+11.4 \%$ & $+37.1 \%$ & $-10.6 \% \neq$ \\
\hline resistance & $-53.9 \%$ & $-41.4 \% \div$ & $-56.7 \% \dagger$ & $+54.89 \%$ \\
\hline
\end{tabular}

Absolute changes analyzed by t-test.

$* \mathrm{P}<0.0001$.

$t \mathrm{P}<0.001$.

$\ddagger \mathrm{P}<0.05$.

All other values statistically not significant.

not seem to alter the antiarrhythmic properties of verapamil or propranolol.

Analysis of antiarrhythmic efficacy by simple arrhythmia control in aminophylline toxic dogs has severe inherent limitations since previous researchers ${ }^{4}$ have demonstrated that these arthythmias are often short-lived and self-terminating. This electrophysiologic behaviour clearly precludes simple arrhythmia control as an effective therapeutic endpoint, since terminating a seemingly stable arrhythmia after the administration of any given drug could be a coincidence which might not necessarily reflect antiarthythmic effectiveness. For these reasons we had to create a reliable and reproducible manoeuvre, capable of consistently triggering ventricular arrhythmias. Acute blood pressure elevation by intra-aortic balloon inflation or incremental boluses of phenylephrine always resulted in the emergence of ventricular arthythmias in aminophylline toxic dogs. Since both hypertensive manoeuvres were effective in generating ventricular arrhythmias we elected the latter, for practical reasons. Although it has been demonstrated that phenylephrine can produce an increase in myocardial cyclic AMP in vitro, this effect has not been shown in the intact animal. ${ }^{6}$ Therefore we do not think that the arrhythmias precipitated by this pressor agent were secondary to its cellular effects. In this context, acute intra-aortic balloon inflation, a manoeuvre devoid of similar cellular effects, was also effective in consistently eliciting ventricular arrhythmias in the aminophylline toxic dog. These observations were in sharp contrast to previous studies demonstrating that an acute blood pressure elevation has a protective effect against ventricular arrhythmias in the $\operatorname{dog}^{7}$

Although we did not include a His bundle recording for the documentation of these arrhythmias the criteria previously described provided strong evidence in favour of a ventricular origin. Moreover these arrhythmias proved to be lethal in the untreated control group.

Unfortunately the cellular mechanisms underlying aminophylline-induced arrhythmias remain only partially understood. Our observations do not allow us to establish whether this electrophysiologic behaviour is secondary to abnormal automaticity, re-entry or oscillatory after-potentials. This study did demonstrate that sudden myocardial and

TABLE V Arrhythmia control and recurrence

\begin{tabular}{llll}
\hline & $\begin{array}{l}\text { Arrhythmia } \\
\text { generated }\end{array}$ & $\begin{array}{l}\text { Arrhythmia } \\
\text { control }\end{array}$ & $\begin{array}{l}\text { Arrhythmia } \\
\text { recurrence } \\
\text { * }\end{array}$ \\
\hline $\begin{array}{l}\text { Group II } \\
\text { (verapamil) } \\
\mathbf{n}=6\end{array}$ & 6 & 6 & 0 \\
$\begin{array}{l}\text { Group III } \\
\text { (propranolol) } \\
\mathrm{n}=6\end{array}$ & 6 & $3 \ddagger$ & 4 \\
\hline
\end{tabular}

"P $=0.03$ (Fisher's exact test).

†Initial dose.

$\ddagger$ Second dose. 


\section{$\mathrm{NS} \rightarrow$ NOT SKGNIFICANT}

$X X \rightarrow P<0.0005$

$X-P<0.05$

ALVALES MEAN \pm SO

$0 \rightarrow$ SINGLE OBSERVATION

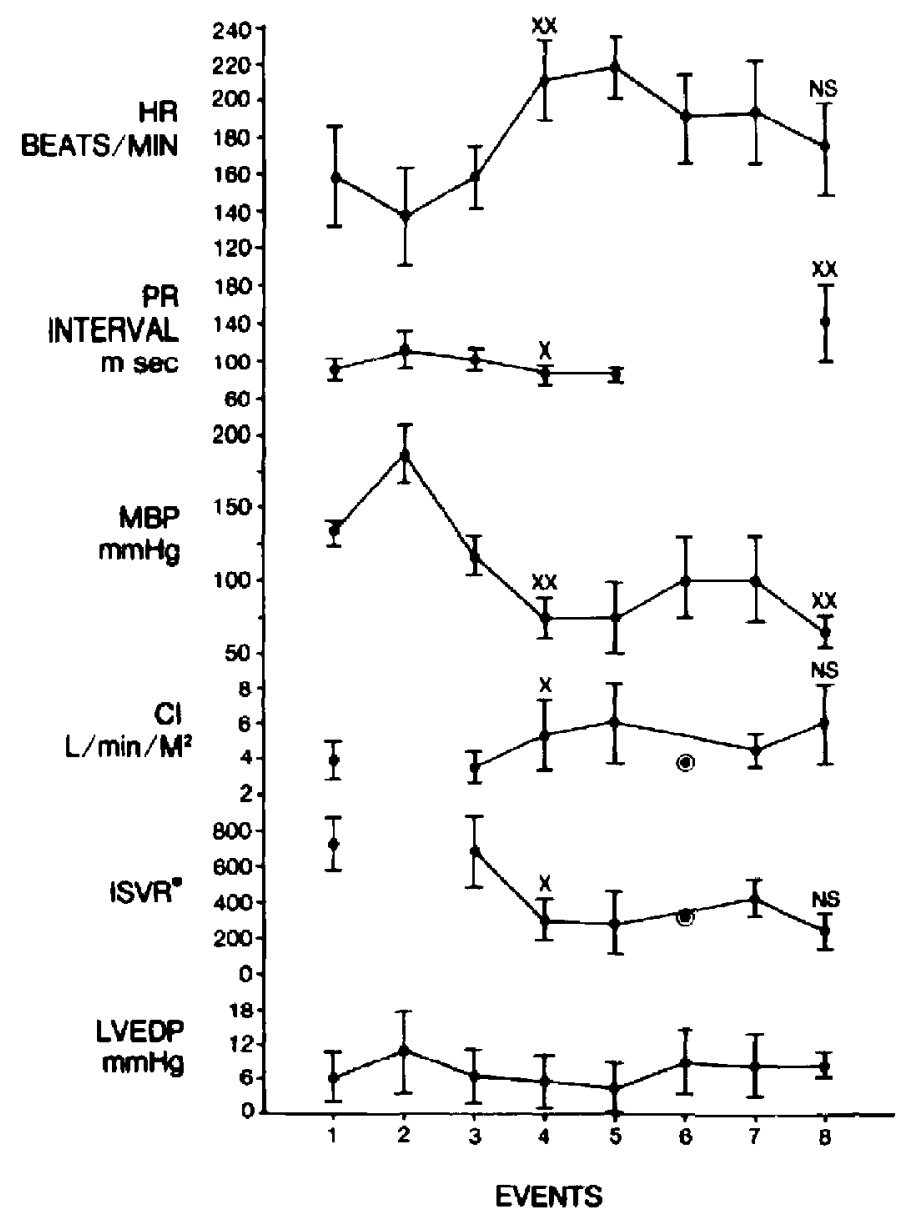

FIGURE 3 Electrophysiologic and haemodynamic parameters observed in Group II (verapamil treated). HR - Heart rate; MBP - Mean artcrial blood prossure; CI - Cardiac index; ISVR - Systemic vascular resistance; EVENTS 1-8 summarized in Table I.

purkinje fiber stretch, accomplished by sudden hypertension, played a crucial role in the initiation of these arrhythmias. ${ }^{8}$ In addition, these observations showed the crucial interaction between the mechanical and electrical behaviour of the heart, but more importantly highlighted the potential deleterious effects of pressor agents in the treatment of hypotension secondary to aminophylline toxicity.

Verapamil, apart from its central cardiac effects, is a potent peripheral vasodilator. ${ }^{9}$ The antiarrhythmic properties demonstrated were independent of 


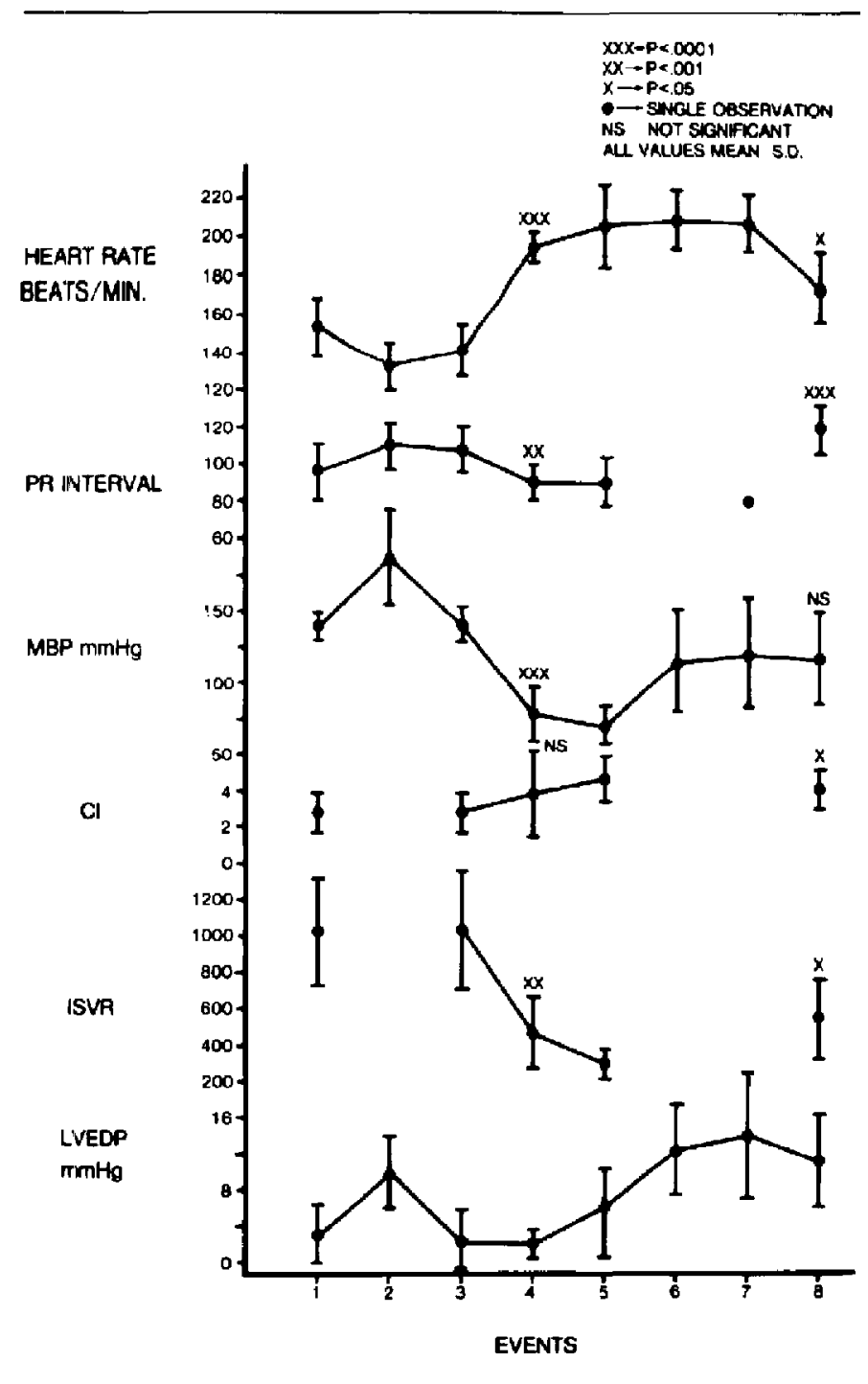

FIGURE 4 Electrophysiologic and haemodynamic parameters observed in Group III (propranolol treated). Abbreviations and events as per Figure 3.

its effects on blood pressure and systemic vascular resistance since subseguent pressure challenges to arhythmogenic pre-verapamil levels were ineffective in re-instituting these ventricular arrhythmias. An antiarrhythmic effect secondary to a drop in blood pressure was further excluded by producing profound hypotension induced by opening an arteriovenous shunt without observing rhythm conversion (unpublished data). Furthermore, during stable ventricular tachycardia some of the animals showed profound and persistent hypotension which not only did not result in spontaneous conversion, but if left 
untreated always degenerated into terminal ventricular fibrillation (Group I).

Propranolol appeared a less effective antiarrhythmic than verapamil since it did not completely suppress the arthythmias in three dogs and could not prevent the re-emergence of ventricular ectopics in four following a repeat phenylephrine challenge (Table V).

Although verapamil had more statistically and clinically significant adverse effects than propranolol they were short-lived and self-terminating. Other investigators have suggested that the hypotension associated with intravenous verapamil administration is related to the rate of administration. ${ }^{10}$ Therefore, it is conceivable that the profound haemodynamic changes seen with the administration of verapamil in this study were related to administration rate. Verapamil was a more effective antiarrhythmic than propranolol in the aminophylline toxic dog model as described above. Perhaps more importantly it should be realized that propranolol therapy is a relative contraindication for those with asthma, a condition commonly treated with aminophylline.

Despite the effectiveness of these antiarnythmics in the presence of high aminophylline levels as described in this animal model, it is difficult to predict their usefulness in aminophylline toxic patients.

Finally the predictable nature and ease of induction of these aggressive ventricular arrhythmias, highlights the potential usefulness of this animal model for the study of many other electrophysiologic problems.

\section{Acknowledgements}

The authors gratefully thank Usha Schick for technical assistance, Marvin Dlugosh for medical graphics, and Barbara Brandstrom for expert secretarial assistance.

\section{References}

1 Ehiers SM, Zaske DE, Sawchuk RJ. Massive theophylline overdose - rapid elimination by charcoal hemoperfusion. JAMA 1978; 240: 474-5.

2 Szekeres $L$. Methods for evaluating antiarthythmic agents in: Schwartz A. ed. Methods in Pharmacology, Volume 1, Meredith Corp. N.Y., pp. 151-90 (1971).

3 Strit JA, Sullivan SF. Aminophylline: review article. Anesth Analg 1981; 60: 587-602.

4 Strit $J A$, Berger $J M$, Ricker $S M$, Sullivan SF. Atrhythmogenic effects of aminophylline during halothane anesthesia in experimental animals. Anesth Anaig 1980; 59: 410-6.

5 Sugiura M, Ogawa K, Yamazaki N. Concentration of myocardial cyclic AMP and ventricular fibrillation induced by aminophylline. Jpn Heart J 1979; 20: $177-82$

6 Blaiklock RG, Hirsh EM, Lehr D. Effect of cardiotoxic doses of adrenergic amines on myocardial cyclic AMP. J Molecul Cellul Cardiol 1978; 10; 499-509.

7 Blat $C M$, Verrier $R L$, Lown $B$. Acute blond pressure elevation and ventricular fibrillation thrcshold during coronary occlusion and reperfusion in the dog. Am J Cardiol 1977; 39: 523-8.

8 Waxman MB, Wald RW, Finley JP, Bonet $J F_{1}$ Downar $E$, Sharma A. Valsalva termination of ventricular tachycardia. Circulation 1980; 62 : 843-51.

9 Stone PH, Antman EM, Muller JE, Braunwald E. Calcium channel blocking agents in the treatment of cardiovascular disorders. Part II: Hemodynamic effects and clinical applications. Ann Intem Med 1980; 93: 886-904.

10 Kapur PA, Flacke WE. Epinephrine-induced arthythmias and cardiovascular function after veraparnil during halothane anesthesia in the dog. Anesthesiology 1981; 55: 218-25. 
Résumé

L'inguence des agents anti-arythmiques bloquant de calcium vérapamil et le bloquant récepteur du betaadrénergique propanolol ont été étudiés chez des chiens recevant l'aminophylline en doses toxiques. On a employé l'intubation et ta ventilation chez dix-huit chiens ayant reçu l'induction de l'anesthésie avec du pentobarbitone $30 \mathrm{mg} / \mathrm{kg}$ et du pancuronium $0.1 \mathrm{mg} / \mathrm{kg}$. Tous les animaux devinrent toxiques après l'infusion d'amino. phylline, une dose initiale de $50 \mathrm{mg} / \mathrm{kg}$ dans l'intervalle de cinq minutes et des doses subséquentes de $10 \mathrm{mg} / \mathrm{kg}$ pendant 30 secondes. Vingt minules après l'infusion d'aminophyline, on provoque le chien avec de la phényléphrine ( $10-20 \mu \mathrm{g} / \mathrm{kg})$. Cette infusion provoque une courte durée d'hypertension et l'émergence reproductible d'arythmies ventriculaires. On a divisé ces chiens en trois groupes de six. Le groupe I (témoin) n'a pas reçu d' agents anti-arythmiques alors que le groupe II reçul le verapamil $(0.2 \mathrm{mg} / \mathrm{kg})$. le groupe III, le propanolal $0.1 \mathrm{mg} / \mathrm{kg}$ pour le traitement d'arythmies ventriculaires persistentes. Les deux agents verapamil et propanolol exercèrent un effet anti-arythnique sur les arythmies ventriculaires causées par l'aminophylline. L'efficacité du vérapamil est indépendente de la réduction causant fa tension artérielle ex la résistance artérielle systémique puisque l'hypertension provoque par la phényléphrine ne pouvait pas réinstituer ces arythmies. Le propanolol semble avoir moins d' efficacité puisqu' il $n$ 'inhibe pas complètement les arythmies chez trois chiens et n'empêche pas l'émergence du PVC apres les doses répétées provocatrices de phényléphrine. De plus amples études sur ce modèle d' animal pourraient être utiles dans le bu! d' améliorer nos connaissances sur les arythmies ventriculaires. 